\title{
The Value of Geneva Association Membership and the Bond of Information on Insurance
}

\author{
by John Robins*
}

In June 1973 The Geneva Association was formed in order to study and analyse the problems relating to insurance economics by means of research, the organisation of international seminars on topics of interest for the development of insurance and by means of publications. In other words, their objective was to disseminate more and better information about the insurance industry as it then was.

In the past 25 years there has been an absolute transformation of the insurance industry for all the participants :

- For consumers and corporate policyholders

- For intermediaries

- For the insurance risk carriers

and information has been at the heart of that transformation.

It has recently been said about the financial services industry in the UK that there are no more "Dumb Customers" and this applies equally to individual and corporate customer. Information is now freely available on the relative price of insurance and policy coverages are much more transparent. One reason is the growth of simplified distribution methods and the need to be able to ensure that what is being sold is clear even during brief telephone conversations. Regulators and Government also strive to make sure that the public have more and better information before risk coverage decisions are

The importance of insurance coverage has grown as the scale and complexity of risks for commercial customers have grown and a new body of professional risk manager have

\footnotetext{
* Group Chief Executive, Guardian Royal Exchange, London.
} 
grown around the world, who have delved deeper and deeper into the information available to insurance companies about the risks that they should cover and the associated costs.

Information has certainly helped the customer become better informed and to buy better with a consequence on prices. Lower prices in turn have forced the need for further cost cutting, which in turn has added to the momentum for mergers. Clearly also crossborder purchasing will soon accelerate in Europe in a much more advanced form with the advent of the Euro and it will be interesting to see the spread of information about comparative policy coverages and the price reductions that will follow those events.

For the intermediaries this relentless spread of more information has meant that their profitability has been squeezed. The policyholder have easier access to information and alternatives. Corporate customers have information about the profitability of their account and of the amount of money that is made by the intermediaries. As a consequence they are better placed to make decisions on which risks they should put into the market or through alternative risk transfer mechanisms.

Information used to be at the heart of the rationale for the use of an intermediary but with the advent of computerised database and professional buyers that information has been spread widely.

And the Risk Carriers themselves? The heart of the membership of The Geneva Association (as the membership comprises of the Chief Executive Officers of insurance companies). Information has created a major squeeze on their profitability and indeed has reinforced the need for a significant change.

Intermediary power has meant that information on the profitability of the Insurance business placed is now available as well as volumes placed world-wide and intermediaries inevitably, being squeezed on one side wish to take advantage of this information to ask gently the companies to contribute to their ability to pay dividends to their shareholders!

Amidst all this growth of information The Geneva Association has continued to provide better and deeper information on the workings of the insurance industry and the major issues that face Governments and customers. The value of being a member of The Geneva Association means that one is continually dealing with strategic information of the very highest quality and from people who understand the background of that information and who are not just interested in producing information for information's sake. The Geneva Association's annual meeting brings together Chief Executives from around the world and major emerging issues are discussed very openly and frankly. The information that is thus gleaned is of assistance not only to the companies, but also to the trade associations, in how those matters should be handled to improve the position with Regulators and Governments and indeed to assist Governments to formulate policies on which the insurance industry can help.

There is absolute certainty that the insurance industry will continue it's rapid transformation and The Geneva Association, providing information on future possibilities and structures, will be at the heart of that transformation for the next 25 years. 